\title{
11. Vad säger (inte) en kursplan? En blick på utbildningen i franska från 1960-talet till i dag
}

\author{
Katharina Vajta
}

\subsection{Inledning}

Kursplanen ${ }^{72}$ anger ett visst kunskapsinnehåll och de villkor som gäller för dess förvärvande. Den blir därmed i hög grad ett aktivt, styrande dokument. Universitetskanslerämbetet (UKÄ) konstaterar att kursplaner "hör till de främsta styrdokument som finns vid ett lärosäte" och att de utgör "föreskrifter [och] regler som är [...] bindande för såväl högskolan som studenter" (UKÄ Rapport 2014:16, s. 17). Det är det enda dokument för högre utbildning vars förekomst är reglerad i Högskoleförordningen (HF 2006:1053, \$14, $\$ 15)$, som stipulerar vad som där ska anges, nämligen kursens nivå, antal högskolepoäng ${ }^{73}$, mål, krav på särskild behörighet, former för bedömning och övrigt som behövs (HF 2006:1064). Vid Göteborgs universitet (GU) styrs kursplaner också av lokala regler (GU 2015) och indirekt även av den mall som kursplanedatabasen GUBAS tillhandahåller. De ska vara fastställda av den instans som anges i lärosätets arbetsordning och deras officiella och juridiska status som tvingande dokument medför att de ska diarieföras och arkiveras, vilket också möjliggör en granskning över tid. Deras särskilda ställning bland högskolans dokument borde rimligen medföra en lika stor omsorg om deras innehåll och utveckling, och förändringar över tid kan förväntas spegla förändringar inom ett ämne och en utbildning.

I det som följer kommer jag efter en kortfattad forskningsöversikt att gå igenom studie- och kursplaner i franska vid Göteborgs universitet sedan 1960-talet, och se på deras utveckling vad gäller främst innehåll, examinationsformer och lärandemål. Avslutningsvis kommer jag att summera det som kan utläsas i dokumenten. Som allmän bakgrund till detta ligger den svenska högskolans utveckling och även det enskilda lärosätets (GU), vilket

72 Tack till Mårten Ramnäs, tidigare studierektor för franska och arabiska vid institutionen för språk och litteraturer, Göteborgs universitet, för kommentarer och synpunkter på denna artikel.

73 Poäng enligt det äldre systemet med 20 poäng per termin har här genomgående räknats om till högskolepoäng: 20 poäng blir alltså 30 högskolepoäng, 5 poäng blir 7,5 högskolepoäng, osv. 
innebär att mångt och mycket inte är specifikt för franskan i Göteborg eller ens franskämnet över huvud taget, och att ämnets utveckling i viss mån också kan få en mer allmän bäring.

\subsection{Bakgrund}

\subsubsection{Tidigare forskning om kursplaner}

Ordet kursplan översätts ofta med engelskans syllabus (pl. syllabi) eller course syllabus, bland annat av Universitets- och högskolerådet (uhr.se), som även anger alternativet course specification. ${ }^{74}$ Och det är just syllabus som varit föremål för den mesta forskningen inom området, medan forskning om svenska kursplaner på universitetsnivå förefaller närmast obefintlig. Icke desto mindre framstår mycket av den forskning som gjorts på syllabi som relevant för kursplaner, även om en syllabus inte helt kan jämföras med en kursplan eftersom den också innehåller annan information, till exempel schema och datum för examinationer. En syllabus motsvarar alltså snarare en kombination av en kursplan och vad som ibland kallas kursguide, ett dokument där lärare ger information om alltifrån själva undervisningen, kursupplägget och examinationer till praktiska tips och annat som anses relevant för kursen (Aldrin 2012: 7). En svensk kursplan omfattar ett flertal formella punkter men lämnar ändå viss frihet att formulera sig, inte minst i beskrivningen av kursens innehåll, vilket kan möjliggöra att urskilja olika stilar. Men den ger inte läsanvisningar, information om schema eller annat som hör till kursens upplägg.

Vanliga sätt att betrakta en syllabus är att se den som ett kontrakt mellan studenten och den som ger utbildningen (läraren, lärosätet), som en förteckning över innehåll, kurskrav mm, och som ett verktyg för lärande (Bowers-Campbell 2015; Parkes \& Harris 2002). Fornaciari \& Lund Dean (2014: 705) identifierar fyra olika infallsvinklar: "syllabus as contract, syllabus as power instrument, syllabus as communication or signaling device, and syllabus as collaboration". De anser att de två första "typically builds a wall between the student and the teacher" och att kontraktsmodellen motsvarar en studentsyn där studenten blir till ett objekt att manipulera (id., 2014: 718). Att en kursplan också blir ett styrande verktyg för en kurs är något

74 Även termen curriculum förekommer, men då ofta i en bredare betydelse än syllabus. 
som ofta åsidosatts, utan forskningen har mest inriktat sig på vår förståelse av själva lärandeprocessen (id., 2014: 702), inte på hur den bestäms genom en syllabus. En sådan bestämmer i hög utsträckning den kurs den avser: Fokus ligger främst på vad som ska läras, däremot sägs det sällan något om hur eller varför (id., 2014: 707). En syllabus blir inte bara ett verktyg, den utgör också en egen genre bland akademiska dokument. Afros \& Schryer (2009: 225) anser att det är "one of the most recognizable instantiations of academic genres" som tillhandahåller retoriska strategier för att beskriva till exempel kurs och lärandemål, och till exempel Baecker (1998) har undersökt användningen av personliga pronomen och hur $I$, we och you används.

Parkes \& Harris (2002: 57) konstaterar att en syllabus också kan utgöra ett relevant dokument för externa granskare av utbildningen, som då kan bilda sig en uppfattning av kursens innehåll och mål. Kursplaner ses som en indikator på kvalitet och det var för att svara mot de krav på förbättring av universitetsutbildningen som de infördes på 1940-talet och då "reglerade undervisningen och därmed begränsade lärarnas frihet" (Andrén 2013: 74). Helt följdriktigt ingår de bland de dokument som externa bedömare ska gå igenom i samband med en kvalitetsgranskning (se GU:s Kvalitetspolicy). Vad som rekommenderas att ingå i en syllabus (Afros \& Shryer 2009: 226) är också mycket av det som måste ingå i en kursplan: kursens syfte och innehåll, en beskrivning av kursens olika moment, former för examination och bedömning återfinner vi i kursplanen, om än i mer avskalad form. Den kan även vara ett sätt att socialisera och föra in studenten i den akademiska världen och ämnets egen kultur och forskningsfält, till exempel genom att använda en vetenskaplig terminologi (id., 2009: 229). Och redan 1945 års universitetsberedning fastslår att forskning och undervisning hör samman, konstaterar Andrén (2013: 25). Vidare skriver Andrén:

Principen att forskning och utbildning oskiljaktigt hör samman och inte får isoleras från varandra [...] går som en röd tråd genom debatten om utbyggnaden av svenska universitet och högskolor. [...] Från 1945 års universitetsberedning och fram till dagens debatt har det rått en total enighet om att denna princip ska vara vägledande. Utbildningen ska vila på vetenskaplig grund och sådan uppnås först genom det direkta sambandet mellan forskning och utbildning. Något annat alternativ har inte heller presenterats. Däremot finns det, som vi sett, divergerande tolkningar 
av den konkreta innebörden av principen och hur den skulle omsättas i praktiken. (Andrén 2013: 63-64)

Diskussionen om utbildningens forskningsanknytning är således inte ny och den har förmodligen blivit än mer aktuell de senaste åren, i takt med att högskolan vuxit, studenterna blivit fler och allt större delar av årskullarna gått vidare till högre studier. Vad anknytningen till forskning egentligen innebär är dock inte entydigt, utan kan bland annat tolkas som att det ska vara forskningsutbildade och disputerade lärare, att undervisningen ges av en utbildningsinstans som även bedriver forskning eller att den är grundad i aktuella forskningsresultat (se Sadurskis 2015: 6; Haikola 2015: 313-314; HSV Rapport 2006:46, s. 24-27).

\subsubsection{Högskolereformer och ämnesutvärderingar}

Sedan 1960-talet har flera stora reformer genomförts inom den svenska universitetsvärlden: 1977, 1993, den så kallade Bolognareformen med Högskolereformen 2007 och Autonomireformen 2011.

I och med 1977 års reform utvidgas hela högskolesektorn genom att bland annat lärar- och vårdutbildningar integreras med högskolan då "så gott som all postgymnasial utbildning sammanfördes under det kollektiva begreppet högskolan” (HSV Rapport 2006:3, s. 11). Fakultetsnämnder ersätter fakultetssammanträden och "fokus i reformen 1977 [kom] att till stora delar handla om att skapa förutsättningar för nationell planering genom ett fast linjesystem, ett centralt antagningssystem, gemensam poängberäkning och en utpräglad modularisering av studiegången" (Lindberg-Sand 2008: 29). Denna modularisering innebär en uppdelning av utbildningen i självständiga moduler och enheter (fristående kurser), som kan fogas samman till en utbildning. Ett hundratal olika utbildningslinjer inrättas, förutom dem på lokal nivå (HSV Rapport 2006:3, s. 9). Organisationen av utbildningen förändras alltså, men pedagogiken inom högskolan är föremål för stark kritik, inte minst från Sveriges Förenade Studentkårer. Denna kritik går bland annat ut på att många lärare saknar pedagogisk utbildning, att pedagogisk erfarenhet inte värderas i samband med tjänstetillsättningar, att examinationen inte motsvarar målen och att kursvärderingar saknas (HSV Rapport 2006:3, s. 14, 53). 
Nästa reform följer 1993. Den fortsätter att decentralisera beslutsmakten och statsmaktens inflytande minskar (HSV Rapport 2006:3, s. 14-15), och innebär införandet av en examensordning, en förstärkning av systemet med fristående kurser, och att högskolans finansieringssystem ska baseras på en tilldelning per student, vilket gäller än i dag (se Haikola 2015: 45-49, 71-78.) Därmed följer att utbildningarnas kvalitet hamnar i blickfånget och att utvärderingsverksamheten blir alltmer systematisk (Schoug 2006: 64). Språken i allmänhet och då förstås även franskan utvärderas i olika omgångar, först av dåvarande Högskoleverket (HSV) i början på 2000-talet, därefter av UKÄ 2012. Efter autonomireformen 2011 får lärosätena ansvaret att själva kvalitetsgranska sina utbildningar (se UKÄ Rapport 2014:11).

Den rapport som publiceras 2005 efter utvärderingen av ämnet franska i Göteborg innebär viss kritik av utbildningen. Bedömargruppen konstaterar att det är "svårt att se tydliga mål och visioner" och att kurserna behöver "förnyas för att i större utsträckning [...] anpassas till nyare internationella forskningsrön” (HSV 2005:3, s. 28). Kort därefter kommer så Bolognareformen, som medför en översyn av de flesta utbildningarna, och kursplanerna i franska anpassas till de nya förutsättningarna. I och med denna reform hamnar fokus på lärandemål, resultat och generiska kompetenser (Hesslefors et al. 2010: 4-9); constructive alignment (på svenska: konstruktiv länkning) blir ett begrepp som får stor betydelse då lärandemål, kursinnehåll, examination och undervisning ska kopplas ihop så att målen i kursplanen uppnås på bästa sätt (se Hesslefors et al. 2010: 8, Biggs \& Tang 2011; Butcher 2014: 80-81; Wickström 2015: 4-5). Bolognareformen innebär alltså ett skifte från vad kursen ska ge studenten till att studentens eget lärande sätts i centrum - från vad som ska läras ut till vad studenten ska lära sig och kunna efter avslutad kurs.

Nästa kvalitetsutvärdering äger rum 2012 och det efterföljande beslutet (UKÄ reg nr 411-00298-13) innebär för franskan i Göteborg omdömet hög kvalitet. Då hade redan Autonomireformen trätt i kraft, vilket betyder att svenska lärosäten i fortsättningen får ansvaret för kvalitetsarbetet.

\subsection{Kursplaner i franska vid GU: urval och genomgång}

Urvalet av de kursplaner (se bilaga 1) som här undersökts är gjort utifrån de reformer som högskolan genomgått sedan 1960-talet, så att det för varje 
period valts ut kursplaner för tidigare A-, B- och C-kurser och nuvarande grund-, fortsättnings- och fördjupningskurser. Här kan vi konstatera att de instanser som ska fastställa kursplaner successivt flyttats från nationell nivå (UKÄ) till fakultetsnivå och numera institutionsnivå, i takt med decentraliseringen av utbildningarna (se bilaga 2). ${ }^{75}$ På 1970-talet var A- och B-nivån sammanfogade i en enda kursplan, som då gällde för ett års studier. Det går dock att utläsa vad som hör till första terminen, eftersom det finns en kursplan för enbart A-kursen (dock ingen för en B-kurs då studenter som bestämde sig för att läsa vidare efter en termin fick gå över till AB-kursen).

Kursplanerna har gåtts igenom med avseende på innehåll, examinationsformer och lärandemål. Inom de olika perioderna kan det ha skett vissa mindre revideringar, men allmänt kan vi konstatera att sådana inte var lika vanliga förr. Detta kan tolkas som att det i dag ses som både nödvändigt och önskvärt att uppdatera kursplaner utifrån till exempel nya forskningsrön, eller kursvärderingar och andra synpunkter, och att det också har blivit en något smidigare process då fastställandet numera sker på institutionsnivå.

\subsection{Kurser}

\subsubsection{Period A: Före 1977}

År 1967 fastställer dåvarande Universitetskanslerämbetet en studieplan för franska språket, som då ingår i filosofisk ämbetsexamen (för blivande lärare) och filosofie kandidatexamen. Datum för fastställandet är den 27 juli 1967 och ett par olika exemplar av dokumentet finns arkiverade, varav det ena har en handskriven anteckning "Fastställd 4/9 67", vilket förmodligen egentligen motsvarar tidpunkten för arkiveringen och snarare vittnar om hur denna sköttes. Studieplanen, som i stor utsträckning består av löpande text, stipulerar att ämnet franska "innefattar studiet av det franska språket samt av fransk litteratur och kultur. Språkstudierna är inriktade dels på färdighet i språkets användning, dels på kunskaper om dess struktur och utveckling". (Studieplan 1967, s. 1.)

En första allmän del anger de förkunskapskrav som ställs, vilka innebär såväl betyget Godkänd i studentexamen som "kunskaper i ytterligare ett

75 Kursplaner i franska vid GU fastställs alltså vid Institutionen för språk och litteraturer, dit alla språk (dock ej svenska och nordiska språk) fördes 2009, i samband med en omorganisation av Humanistiska fakulteten vid GU. 
modernt främmande språk på gymnasiets läroplan”. Beskrivningen av "kunskapskontrollen" omfattar de obligatoriska prov och tentamina som ingår med vad som krävs för varje betygsenhet, det vill säga för varje termins studier. En muntlig sluttentamen avslutar varje termin. Studenten förväntas själv i samband med anmälan till denna tentamen lista "de föreläsningar och övningar han bevistat samt den tid han vistats i fransktalande land" (s. 2) - i kursplanen blir studenten en 'han' i utvidgad betydelse, vars utlandsvistelse tas för given, även om studenten i verkligheten förmodligen oftast var en 'hon'. Den andra delen av studieplanen beskriver studiekurser och kursfordringar, och även den mängd litteratur som ska läsas: För en betygsenhet ingår "c. 3.000 sidor verk av representativa franska författare från 1800- och 1900-talen och c. 1.000 sidor sak- och facklitteratur". Texterna ska studeras "dels extensivt, dels intensivt, med den ungefärliga proportionen 3:1". Dessutom ingår bland annat översättning, fonetik, grammatik och ordkunskap.

Den tredje och sista delen ger "Anvisningar och råd" som kan anses riktade till såväl studenter som lärosäte och lärare. Klart och tydligt meddelas här att "undervisningen täcker endast en del av kunskapsfordringarna i ämnet"; övrigt förväntas studenten uppnå genom egna studier och vistelse i landet. Och det fanns stor frihet för institution och lärare att utforma själva utbildningen: Andrén (2013: 74) noterar att det råder "närmast total frihet på verksamhetsnivå”.

Efter PUKAS-reformen 1968 finner vi studieplaner där antalet poäng för varje moment står angivet. De kurser i franska som institutionen för romanska språk vid GU erbjuder 1975 innebär grundkurs $A B 1$ och påbyggnadskurs C1, som var allmänna studiekurser och hade var sin ekonomisk-samhällsvetenskapliga variant (AB2 och $\mathrm{C} 2)$. Båda varianter leder till examen. Dessutom finns en grundkurs A1 efter vilken man kan välja att övergå till $A B 1$. Valet mellan att specialisera sig inom litteratur eller språkvetenskap görs först på den fjärde terminen, med påbyggnadskursen D1 (litterär inriktning) och D2 (språkvetenskaplig inriktning). Till skillnad från tidigare läser studenterna inte längre ett betyg per termin utan poängsystemet med 20 poäng (numera 30 högskolepoäng) per termin har införts, och det finns nu angivet antal poäng för varje delkurs (se HSV Rapport 2006: 3, s. 10). 


\subsubsection{Period B: 1977-1993}

Reformen 1977 syftade bland annat till att"öka utbildningens tillgänglighet, särskilt för andra studerandegrupper än de traditionella, och därmed främja den sociala utjämningen", att "bredda och differentiera det samlade utbildningsutbudet" och att" demokratisera utbildningens organisation och anpassa dess verksamhetsformer till en mer allsidig rekrytering av studerande" (HSV Rapport 2006:3, s. 11; se även Haikola 2015: 40-43.) Men kursplanerna ${ }^{76}$ motsvarar i stort sett de kurser som gavs före reformen. Dock har rubrikerna kompletterats, bland annat med utbildningens syfte. Där anges för kursen $\mathrm{AB} 1$ att den ska "ge allsidig färdighet i användningen av franska språket i tal och skrift samt grundläggande kunskaper om franska språket, Frankrikes litteratur, kultur och samhällsförhållanden.” Kursplanen anger inte längre något förkunskapskrav på annat modernt språk från gymnasieskolan, och någon utlandsvistelse i fransktalande land behöver inte längre redovisas.

Mängden kurslitteratur under första terminen har minskat till knappt 3000 sidor, bedömningsformerna anger "skriftliga och/eller muntliga prov" och det finns inte längre någon muntlig sluttentamen. Ungefär en tredjedel av kurslitteraturen förutsätts läsas intensivt, och två tredjedelar extensivt. Värt att notera är att under denna period, närmare bestämt 1987, ges för första gången grundkursen i Lyon genom ett samarbete med Université Lumière Lyon II, då utifrån samma kursplan som grundkursen i Göteborg. ${ }^{77}$

Fortsättningskursens (B-kursens) moment fördelar sig mellan i huvudsak muntlig och skriftlig språkfärdighet (med grammatik och tema), samt litteratur med litteraturhistoria och sakprosa. Dessutom ingår en delkurs i språkhistoria och vad som då benämns realia, vardera motsvarande 3 högskolepoäng. Tredje terminens C-kurs innebär obligatoriska momenten grammatik, stilistik och vokabulär, översättning till franska (tema) och litteratur med litteraturhistoria, då främst 1600-, 1700- och 1800-tal, men även ca 15 sidor äldre text ingår. Dessutom finns vissa valbara delkurser, som läses på egen hand. Den uppsats som motsvarar dagens kandidatarbete ger 7,5 högskolepoäng och representerar alltså en fjärdedel av kursen.

76 Under denna period heter det fortfarande studieplan, men för enkelhetens skull används här genomgående termen kursplan.

77 Samarbetet med Lyon fortsätter än i dag och har också utökats. 


\subsubsection{Period C: 1994-2006}

Grundkursens angivna mål är att "ge de studerande så god praktisk språkfärdighet att de kan läsa och förstå moderna franska texter och uttrycka sig väl i tal och skrift. Kursen ska dessutom ge teoretiska insikter om franska språket samt kunskap om Frankrikes kulturella, politiska och sociala förhållanden.”

Det muntliga börjar få mer plats inom utbildningen vilket märks på att texterna som studeras nu ska diskuteras och redovisas muntligt i samband med lektionerna. Talfärdighetsmomenten förstärks och kommer in i litteraturstudiet genom diskussion av de lästa romanerna. Antalet textsidor som ska studeras står angivet i kursplanen, och vi kan notera att det krympt ytterligare till att nu bestå av "ungefär 750 sidor representativ skönlitterär text från 1900-talet och 250 sidor sakprosa". Till detta kommer dock "franska texter av realiakaraktär och aktuella tidningsartiklar, totalt ca 350 sidor" i samband med delkursen i realia. Tema (dvs. översättning till franska) är en del av grammatikmomentet. Det anges inte längre hur stor del av texterna som ska läsas intensivt eller extensivt.

På fortsättningskursen upptar översättning till svenska (version) och till franska (tema) sammanlagt 9 högskolepoäng (4,5 vardera), däremot är realiamomentet borttaget. Språkhistoria har en egen delkurs på 3 högskolepoäng. Litteraturdelen omfattar 12 högskolepoäng varav 9 för text från 1800- och 1900-tal, och 3 för litteraturhistoria. Terminen därefter, på fördjupningskursen, fortsätter litteraturstudiet med 1600- och 1700-talet (7,5 högskolepoäng), och språkfärdigheten övas med bland annat grammatik, vokabulär, stilistik och tema (7,5 högskolepoäng). Till detta kommer uppsatsen, som nu omfattar motsvarande 15 högskolepoäng, det vill säga dubbelt så många poäng som tidigare.

En ny rubrik i kursplanen är den om utvärdering. Högskoleförordningen har nämligen år 2000 fått en ny paragraf, som stipulerar att studenterna ska ges möjlighet att framföra sina synpunkter på kursen och från och med nu står det i kursplanerna att varje kurs ska utvärderas "systematiskt och regelbundet" (se HSV Rapport 2004:23). 


\subsubsection{Period D: 2007-2011}

Kursutbudet är i stort sett det samma som tidigare, och förkunskapskravet till det som då hette Grundkurs II $^{78}$ har höjts till gymnasieskolans franska steg 4. Det som ofta kallas Bolognareformen medför bland annat införandet av ett nytt poängssystem där en termins studier motsvarar 30 högskolepoäng och att kursplanerna ska specificera kursens lärandemål. Men utöver anpassningen till detta innebär inte grundkursen någon större innehållsmässig förändring: Tidigare moment disponeras om något, någon högskolepoäng skiljer i fördelningen mellan delkurserna. På papperet har litteraturen fått en mindre del, med 5 högskolepoäng i stället för tidigare dryga 10, men vissa moment inom skriftlig språkfärdighet hänförs till textstudierna och den angivna mängden litteratur har inte minskats - studenten får läsa lika mycket litteratur för motsvarande färre poäng.

Inom fortsättningskursen är förändringen desto mer märkbar. Delkursen i språkhistoria försvinner helt. Obligatoriska är en delkurs i grammatik och skriftlig språkfärdighet om 10 högskolepoäng och en delkurs i muntlig språkfärdighet om 5 högskolepoäng. Utöver detta väljer studenten mellan olika alternativ, närmare bestämt en delkurs om 10 högskolepoäng med kursmoduler omfattande 1800- och 1900-tals litteratur med litteraturhistoria, eller en delkurs benämnd Facktext. För resterande 5 högskolepoäng väljer studenten mellan olika moduler: Kultur och samhälle, Språklig variation i franskan eller Språkvetenskap I (med inriktning mot syntax).

Fördjupningskursen har nu en variant som innebär att studenten i stället för en kandidatuppsats skriver ett kortare specialarbete och den tidigare fackspråkliga varianten har ersatts av denna. På fördjupningskursen med självständigt arbete är endast en delkurs på 5 högskolepoäng i muntlig och skriftlig språkfärdighet obligatorisk. Därutöver skriver studenten ett självständigt arbete (en uppsats à 15 högskolepoäng) och väljer två valbara moduler à 5 högskolepoäng vardera. Förutom de som redan nämnts finns fler valbara moduler med Facktext, Språkvetenskap II (med inriktning mot semantik, pragmatik och översättningsvetenskap), 1600- och 1700-talslitteratur med litteraturhistoria, och Litteraturvetenskaplig teori. Detta

78 Grundkursen hette alltså under vissa år under period C, D och E Grundkurs II, för att särskilja den från Grundkurs I som i sin tur motsvarade tidigare Baskurs. Såväl Grundkurs I som Baskurs är nu borta, och Grundkurs II heter Grundkurs igen. 
innebär att en stor del av delkurserna är riktade mot litteratur i någon form och att det blir fullt möjligt att få en kandidatexamen i franska utan att ha läst någon språkvetenskap, om man bortser från den grammatik som ingår i språkfärdigheten. Omvänt går det att välja bort litteratur och rikta fortsättnings- och fördjupningskursen mot främst facktext; språkvetenskap kan då utgöra en mindre del.

\subsubsection{Period E: 2012-2016}

Bortsett från mindre revideringar (till exempel har delkursen i realia bytt namn till Kultur och samhälle) är grundkursen densamma som tidigare, vilket i praktiken innebär att inga genomgripande förändringar gjorts i den sedan åtminstone period C. Förkunskapskravet till grundkursen sänks till franska steg 3 i syfte att utöka den potentiella rekryteringsbasen. På fortsättnings- och fördjupningsnivå är upplägget detsamma som under period D. Dessutom utvecklas nätundervisning på såväl grundkurs som fortsättnings- och fördjupningskurs, och det utifrån samma kursplaner som för campusundervisning.

\subsubsection{Period F: 2017}

Grundkursen från år 2017 utgår från en helt omarbetad kursplan, där man lyft fram de vetenskapliga aspekterna i utbildningen och aktualiserat innehållet, till exempel med nutida författare inom litteraturdelkursen. Den har delats upp i fyra olika delkurser à 7,5 högskolepoäng vardera: Grammatik och skriftlig språkfärdighet, Fransk litteratur: text och andra medier, Kultur och samhälle och Muntlig franska. Innehållet har uppdaterats till att omfatta litteratur från 2000-talet, andra medier än traditionella romaner (film, tecknade serier och grafiska romaner) och det är inte längre bara Frankrike som står i centrum utan kursen introducerar även "fransktalande världen”. Lärandemålen har omarbetats och innebär också metareflektion kring språk och kultur vilket kan förväntas bidra till effektivare inlärning (Kelly 2014). De tidigare många passiva verben (såsom ges, uppmärksammas, beaktas, beröres, eftersträvas, behandlas) har i stort sett försvunnit. Tilltalet är nu mer personligt och studenten adresseras direkt: "I den här kursen utvecklar du ...", "du får teoretiska verktyg". För första gången görs också forskningsanknytningen explicit: "Samtliga delkursers innehåll belyses med aktuell forskning." 
På fortsättningskursen är de valbara modulerna borta, vilket inte bara medför tydligare progression till fördjupningskursen utan även innebär att studenterna samlas ihop i stället för att spridas på olika moduler och att lärartiden därmed effektiviseras. Kursen består nu av fyra delkurser à 7,5 högskolepoäng vardera: Grammatik, vokabulär och översättning, 1800- och 1900-talslitteratur med litterär analys, Språkvetenskap och Akademisk framställning, en tydligt förberedande delkurs inför det självständiga arbetet på fördjupningskursen, som även den är omarbetad. Förutom själva uppsatsen omfattar den Äldre fransk litteratur (5 högskolepoäng), Översättning och kontrastiv analys (2 högskolepoäng), Språkvetenskaplig metod och tilllämpning (4 högskolepoäng) och Litteraturvetenskaplig teori och metod (4 högskolepoäng). Till skillnad från tidigare måste studenterna här läsa både språkvetenskaplig och litteraturvetenskap teori. Den äldre litteraturen är återigen obligatorisk såsom den var under period C.

\subsection{Lärandemål}

Som nämnts ovan infördes rubriken Lärandemål i kursplanerna i samband med Bolognareformen, vilket innebär att sådana finns med under perioderna $\mathrm{D}, \mathrm{E}$ och $\mathrm{F}$. Detta betyder inte att något som kan liknas vid lärandemål inte fanns tidigare, men det är nu explicit och systematiserat under egen rubrik, som först var Mål under period D för att från och med period $\mathrm{E}$ heta Lärandemål. Från att kursen eller utbildningen under perioderna $\mathrm{A}$ till C ska ge studenten en färdighet eller kunskap, är det från och med period D studenten som står i centrum och som efter avslutad kurs ska kunna förstå, skriva, tillämpa, översätta, uttala, redogöra - aktiva verb ska användas i lärandemålen.

Fram till 2006 står främst språkfärdighet i centrum för utbildningens mål, kopplat till kunskap om Frankrikes litteratur, kultur och samhällsförhållanden. Trots Bolognareformen ser vi därefter till en början att de förväntade studieresultateten lever vidare nästan ordagrant i de meningar som inleder målen, där även förmågan att översätta mellan språken och att analysera skönlitterära texter betonas. Den kommunikativa språkfärdigheten bedöms i förhållande till den Gemensamma europeiska referensramen för språk, och förväntas att efter grundkursen ligga på nivå $\mathrm{B} 2$ under period $\mathrm{D}$, en nivå som dock sänks till B1-B2 under period E. Nivå B2-C1 förväntas 
studenten sedan uppnå genom fortsättningskursen under period $\mathrm{D}$ och $\mathrm{E}$ för att i dag (period F) uppnå nivå $\mathrm{B} 2$, och efter fördjupningskursen C1.

Från och med period E står målen under rubriken Lärandemål, vilka delas in i tre olika underrubriker: Kunskap och förståelse, Färdighet och förmåga, och Värderingsförmåga och förhållningssätt. I kursplanen för grundkursen finns under den sista rubriken ett enda lärandemål, vilket för en universitetskurs skulle kunna anses lite magert, i synnerhet då det inte är självklart enkelt att observera och därmed examinera: Studenten förväntas nämligen kunna "resonera kritiskt och självständigt om vilken betydelse kunskaper inom ämnesområdet har i samhället och om människans ansvar för hur de används”. I dag är detta mål ersatt med tre andra, som innebär att kunna reflektera kring språk, kultur och litteratur, kring studiet av språk och kulturer i allmänhet och även kring det egna lärandet. Såsom tidigare betonas förmågan att översätta, och vad gäller litteratur ska studenten nu kunna använda "adekvat terminologi” för att göra analyser, och då inte bara av litterär prosa utan även av tecknade serier, grafiska romaner och film.

Under period D och E kännetecknas fortsättnings- och fördjupningskursen av ett antal valbara moduler, vilket innebär att det blir problematiskt att ange gemensamma kunskapsmål för hela kursen, då studenterna kan välja att fördjupa sig inom helt olika fält. Denna valmöjlighet finns inte längre i dag, vilket möjliggör att ha samma lärandemål på dessa kurser. På så vis har även progressionen i ämnet blivit tydligare. I lärandemålen förekommer nu termer som "adekvata metoder", "centrala begrepp", "språkvetenskapliga områden", "litteraturvetenskapliga skolbildningar" m.m., vilket tyder på en mer akademiskt förankrad och mindre språkfärdighetsbetonad utbildning. Detta är dock svårt att avgöra enbart på grundval av kursplanerna: Tidigare togs sannolikt bådadera för givet, medan språken allmänt i dag ofta verkar vilja tydligare situera sig som vetenskapliga ämnen genom att lyfta fram det akademiska innehållet (Kelly 2014).

\subsection{Examinationsformer}

Den muntliga sluttentamen som endast fick göras om samtliga övriga prov var avklarade togs bort efter 1977. I stället ska kunskaperna redovisas "inom varje delkurs i skriftliga och/eller muntliga prov". Under period C anges över huvud taget inte några examinationsformer under rubriken "Former 
för bedömning”, där endast betygsskalan står angiven. Detta förefaller inte vara följden av någon glömska, eftersom det visade sig vara fallet för flera olika årgångar av kursplaner under perioden. I stället håller vi för sannolikt att det inte ansågs viktigt att precisera hur ett moment skulle examineras, $\mathrm{i}$ synnerhet då det under följande period D fortfarande inte står mer än att "delkursernas olika moment examineras antingen muntligt eller skriftligt". I praktiken är formerna för bedömning varierade, med salstentamina, skriftliga inlämningar och muntliga redovisningar. Utvecklingen går dock mot allt större precision i kursplanerna, och drivs inte minst av studentorganisationerna, som efterfrågar tydlighet och precision och är kritiska mot otydliga examinationsformer (GUS 2011). I dagens kursplaner är det klart angivet för varje delkurs och moment hur de examineras och formuleringen "och/ eller" är borttagen. ${ }^{79}$

\subsection{Avslutande reflexioner}

Från 1960-talets gemensamma utgångspunkt i form av en enda studieplan för akademiska studier i franska språket, finns det en möjlighet att utbildningarna i franska i dag utvecklats helt olika vid olika lärosäten. Men självklart behöver alla studenter, oavsett vilket lärosäte de studerar vid, ägna sig till stor del åt samma sak: fransk grammatik och litteratur, utvidga sitt ordförråd, få kunskap om de länder där franska talas, osv.

Det har i Göteborg genom åren varit stark fokus på språkfärdighet, förvärvad utifrån studium av framför allt grammatik och översättning till franska, men även text, som enligt de tidigare kursplanerna (period A och B) skulle läsas såväl extensivt som intensivt. Text har tidigare bestått av både skönlitteratur och sakprosa (tre fjärdedelar av sidoantalet respektive en färdedel), men studiet av sakprosa (och därmed förvärvandet av den typen av vokabulär) verkar dock ha gått förlorat, såvida det inte ingår i andra moment som till exempel Kultur och samhälle. Detta framgår dock inte av kursplanerna.

79 Formerna för bedömning saknas visserligen i kursplanen för den grundkurs under period $\mathrm{E}$ som tagits med här, men detta måste förmodas bero på en teknisk miss: De står med i både den tidigare och den senare versionen och har förmodligen fallit bort i samband med den systemuppgradering av kursplanedatabasen GUBAS som gjordes vid den tidpunkten och som bl.a. innebar just den typen av tekniska problem. 
Dagens kursplaner (period F) visar på en tydlig koppling till forskning, såväl genom beskrivningen av kursinnehållet som i lärandemålen, vilket kan ge anledning att undra om detta förr var så självklart att det inte behövde anges explicit. Balansen mellan litteratur- och språkvetenskap är jämn och alla studenter kommer nu i kontakt med båda, vilket inte alltid var fallet under period D och E. I lärandemålen separeras i dag den kommunikativa språkfärdigheten, som anges enligt den europeiska referensramen för språk, från generiska kunskaper och det mer akademiska, som då handlar om att redogöra för ett innehåll på franska, om att tillämpa kunskaper i grammatik och att översätta, om att analysera och reflektera, om att använda adekvata begrepp och metoder. Över tid har formerna för bedömning ändrats från stora tentamina och slutprov till allt fler skriftliga inlämningar, muntliga redovisningar och mindre salstentamina, från prov och "kunskapskontroll" till bedömning i varierade former, för att svara mot olika studenters lärandestilar. Dessutom har språket förändrats från att vara formellt och opersonligt till att studenten tilltalas direkt med "du".

Decentraliseringen av utbildningen från nationell nivå till lärosäte och institution innebär att ramarna för kursplaner har förtydligats och att de i dag i större utsträckning är föremål för anvisningar vad gäller struktur och form. Aldrin (2012: 20) konstaterar att sådan styrning "ökar kvaliteten i kursplanerna vad gäller de generella aspekterna och även transparensen kring mål och innehåll, men [att kursplanerna] distanseras också från själva undervisningen" - hur verkligheten ser ut (och har sett ut) vet egentligen bara berörda lärare och studenter. Kursplanerna har dock blivit alltmer precisa genom åren, inte minst vad gäller innehåll, lärandemål och examinationsformer. När de nu ingår som underlag i kvalitetsgranskningar blir det därför än viktigare att de kompletteras med dokument som anger schema, kursguider, lärarkompetens, allmän studieinformation, läsanvisningar med mera. Kursplaner säger nämligen inte något om till exempel pedagogiska val, hur mycket undervisning som ges eller om progressionen inom en kurs.

\section{Bibliografi}

Afros, Elena \& Catherine F. Schryer, 2009: The genre of syllabus in higher education. Journal of English for Academic Purposes 8. 224-233. 
Aldrin, Viktor, 2012: Kursguiden som instruktion och styrdokument. Konstruktioner och bruk av kursguider vid Göteborgs universitet. PIL-rapport 2012:04. http://pil.gu.se/digitalAssets/1374/1374530_pil_rapport_2012_04_2012-06-19.pdf [2017-09-22]

Andrén, Carl-Gustaf, 2013: Visioner, vägval och verklighet. Svenska universitetens utveckling efter 1940. Lund: Nordic Academic Press.

Baecker, Diann L., 1998: Uncovering the Rethoric of the Syllabus: The Case of the Missing I. College Teaching 46:2. 58-62.

Biggs, John \& Tang, Catherine, 2011: Teaching for Quality Learning at University: What the Student Does. Fourth Edition. Glasgow: Society into Research in Higher Education.

Bowers-Campbell, Joy, 2015: Investigating the Syllabus as a Defining Document. Journal of College Reading and Learning 45:2. 106-122.

Butcher, Chris, 2014: Describing what students should learn. I: Heather Fry, Steve Ketterige \& Marshall, Stephanie, A Handbook for teaching and learning in higher education. New York: Routledge. 80-93.

Fornaciari, Charles F. \& Lund Dean, Kathy, 2014: The 21st-Century Syllabus: From Pedagogy to Andragoy. Journal of Management Education 38(5). 701-723.

GU 2015, dnr V 2015/1007. Regler för kursplan på grund- och avancerad nivå, rektorsbeslut 2015-12-07. http://medarbetarportalen.gu.se/digitalAssets/1555/1555943_v2015-1007-regler-f--r-kursplan-p---grund--och-avancerad-niv-----beslutad.pdf [2017-09-22]

GUS 2011. Lärandemål och examinationsform - en granskning av kursplaner på utbildningsprogrammen vid Göteborgs universitet. Göteborgs universitets studentkårer. http://gus.gu.se/digitalAssets/1319/1319542_l--randem--1-och-examinationsform.pdf [2017-09-22]

Haikola, Lars, 2015: Högre utbildning under tjugo år. Statens offentliga utredningar SOU 2015:70. http://www.regeringen.se/contentassets/ 18f07e4081134302a3c546341337cdff/hogre-utbildning-under-tjugo-ar-sou_2015_70.pdf [2017-09-22]

Hesslefors, Elisabeth, Carle, Jan \& Engberg, Heléne, 2010: Bolognaperspektiv. Om progressionslinjer inom Lärarprogrammet vid Göteborgs universitet. Dnr G 219 2781/10. http://www.goteborgsuniversitet.se/digitalAssets/1315/1315536_pm_progressionslinjer_100616_-slutversion.pdf [201709-22]

HSV Rapport 2004:23: Högskoleverket 2004. Kursvärdering för studentinflytande och kvalitetsutveckling. En antologi med exempel från elva lärosäten. http://www.uka.se/download/18.12f25798156a345894e297d/1487841893141/0423R.pdf [2017-09-22] 
HSV Rapport 2005:3: Utvärdering av grund- och forskarutbildning i romanska språk vid svenska universitet och högskolor. Del III: franska. http://www.uka. se/download/18.12f25798156a345894e2ae8/1487841914557/0503R-3.pdf [2017-09-22]

HSV Rapport 2006:3: Högre utbildning och forskning 1945-2005. http://uka. se/download/18.12f25798156a345894e28c0/1487841897908/0603R.pdf [2017-09-22]

HSV Rapport 2006:46: Utbildning på vetenskaplig grund. Röster från fältet. http://uka.se/download/18.12f25798156a345894e28b9/1487841897175/ 0646R.pdf [2017-09-22]

Högskoleförordningen (HF): http://www.riksdagen.se/sv/dokument-lagar/dokument/svensk-forfattningssamling/hogskoleforordning-1993100_sfs-1993-100 [2017-09-22]

Kelly, Michael, 2014: Modern languages. I: Fry, Heather, Ketterige, Steve \& Marshall, Stephanie, A Handbook for teaching and learning in higher education. New York: Routledge. 293-310.

GU:s kvalitetspolicy: http://medarbetarportalen.gu.se/kvalitetsarbete/kvalitetspolicy/;jsessionid=w4g0wdt88xhj12pkmkld89aaw?skipSSOCheck=true [2017-09-22]

Lindberg-Sand, Åsa, 2008: Läranderesultat som utgångspunkt för högskolans kursoch utbildningsplaner. Lund, Centre for Educational Development (CED).

Parkes, Jay \& Harris, Mary B., 2002: The Purposes of a Syllabus. College Teaching 50:2. 55-61.

Sadurskis, Aija. 2015: Högre utbildning och forskningsanknytning. Universitetskanslerämbetet. (www.uka.se)

Schoug, Fredrik, 2006: Den kvalitetsmärkta högskolan. Utbildning \& Demokrati 15:2. 63-80.

UKÄ beslut reg nr 411-00298-13. http://www2.uk-ambetet.se/download/ kvalitet/romanska-sprak-2012.pdf [2017-09-22]

UKÄ Rapport 2014:11: Att utvärdera resultat i högre utbildning. Reflektioner kring det svenska utvärderingssystemet. http://www.uka.se/download/18.73 91c377159bc0155b848/1487841865460/rapport-2014-10-03-att-utvardera-resultat-i-hogre-utbildning.pdf [2017-10-03]

UKÄ Rapport 2014:16: Högkolans regler i praktiken - erfarenheter från Högskoleverkets tillsynsbesök 1998-2012. http://www.uka.se/download/18. 12f25798156a345894e4cba/1487841873862/rapport-2015-01-19-hogskolans-regler-i-praktiken.pdf [2017-03-05]

Wickström, Johan, 2015: Dekonstruerad länkning. En kritisk läsning av Constructive Alignment inom svensk högskolepedagogik och pedagogisk utveckling. Utbildning \& Demokrati 24:3. 1-23. 


\section{Bilagor}

Bilaga 1: Urval studerade kursplaner

\begin{tabular}{|c|c|c|c|c|}
\hline \multicolumn{2}{|c|}{$\begin{array}{l}\text { Kursen ges under } \\
\text { följande perioder: }\end{array}$} & Grundkurs & Fortsättningskurs & Fördjupningskurs \\
\hline \multirow[t]{3}{*}{ A } & \multirow[t]{3}{*}{ Före 1977} & \multicolumn{3}{|c|}{$\begin{array}{l}\text { Studieplan för examensämnet franska språket i filosofisk ämbetsexamen och } \\
\text { filosofie kandidatexamen vid universitetet i Göteborg; fastställd av univer- } \\
\text { sitetskanslerämbetet, såvitt avser filosofisk ämbetsexamen gemensamt med } \\
\text { skolöverstyrelsen, den } 27 \text { juli } 1967 \text {. }\end{array}$} \\
\hline & & \multicolumn{3}{|c|}{$\begin{array}{l}\text { Studieplan för examensämnet franska språket, normalstudieplanen fastställd } \\
\text { 18.4.1969. Gäller vid universiteten i Uppsala, Lund, Göteborg, Stockholm } \\
\text { och Umeå, samt vid dåvarande universitetsfilialerna i Linköping, Örebro, } \\
\text { Karlstad och Växjö. }\end{array}$} \\
\hline & & $\begin{array}{l}\text { Studieplan Grundkurs } \\
\text { A1 i franska, } 20 \text { poäng, } \\
\text { fastställd } 1975-12-05\end{array}$ & $\begin{array}{l}\text { Studieplan Grundkurs } \\
\text { AB1 i franska, } 40 \text { poäng } \\
\text { inkl. grundkurs A1, } \\
\text { fastställd 1975-12-05 }\end{array}$ & $\begin{array}{l}\text { Studieplan } \\
\text { Påbyggnadskurs C1 i } \\
\text { franska, } 20 \text { poäng, } \\
\text { fastställd } 1975-12-05\end{array}$ \\
\hline B & $1977-1993$ & $\begin{array}{l}\text { FR1AO, franska, allmän } \\
\text { inriktning, } \\
\text { fastställd 1979-07-01 }\end{array}$ & $\begin{array}{l}\text { FR7BO, franska, } \\
\text { litterär-språkvetenskaplig } \\
\text { inriktning. } \\
\text { Omfattar } 40 \text { poäng, } \\
\text { inkl. det som motsvarar } \\
\text { FR1AO. } \\
\text { Fastställd 1978-07-01 }\end{array}$ & $\begin{array}{l}\text { FRG77, franska } \\
\text { fördjupningskurs, } \\
\text { fastställd 1991-00-00 } \\
\text { (sic!) }\end{array}$ \\
\hline C & 1994-2006 & $\begin{array}{l}\text { FR0200 Grundkurs, } \\
\text { allmän inriktning, } 20 \\
\text { poäng, fastställd 2002- } \\
01-21\end{array}$ & $\begin{array}{l}\text { FR3300 } \\
\text { Fortsättningskurs, } \\
\text { allmän inriktning, } 20 \\
\text { poäng, fastställd 2002- } \\
01-21\end{array}$ & $\begin{array}{l}\text { FR4200 Fördjup- } \\
\text { ningskurs } 1 \text {, allmän } \\
\text { inriktning, } 20 \text { poäng, } \\
\text { fastställd } 2000-12-18\end{array}$ \\
\hline $\mathrm{D}$ & $2007-2011$ & $\begin{array}{l}\text { FR1101, Grundkurs } \\
\text { II, } 30 \text { högskolepoäng, } \\
\text { fastställd 2006-11-20 att } \\
\text { gälla fr.o.m. ht } 2007 .\end{array}$ & $\begin{array}{l}\text { FR1200, } \\
\text { Fortsättningskurs, } 30 \\
\text { högskolepoäng, fastställd } \\
2006-11-20 \text { att gälla } \\
\text { fr.o.m. ht } 2007 .\end{array}$ & $\begin{array}{l}\text { FR1300, Fördjup- } \\
\text { ningskurs, } 30 \text { hög- } \\
\text { skolepoäng, fastställd } \\
\text { 2006-11-20 att gälla } \\
\text { fro.m. ht } 2007 .\end{array}$ \\
\hline
\end{tabular}




\begin{tabular}{l|l|l|l|l}
\multicolumn{2}{l|}{$\begin{array}{l}\text { Kursen ges under } \\
\text { följande perioder: }\end{array}$} & Grundlkurs & Fortsättningskurs & Fördjupningskurs \\
\hline E & 2012-2016 & $\begin{array}{l}\text { FR1101, Grundkurs } \\
\text { II, 30 högskolepoäng, } \\
\text { fastställd 2010-12-21, } \\
\text { reviderad 2012-12-18 att } \\
\text { gälla fr.o.m. 2013-01-18. }\end{array}$ & $\begin{array}{l}\text { FR1200, } \\
\text { Fortsättningskurs, 30 } \\
\text { högskolepoäng, fastställd } \\
\text { 2006-11-20 reviderad } \\
\text { 2013-03-06 att gälla } \\
\text { fr.o.m. 2013-03-06. }\end{array}$ & $\begin{array}{l}\text { FR1300, Fördjup- } \\
\text { ningskurs, 30 } \\
\text { högskolepoäng, } \\
\text { fastställd 2011-04-06 } \\
\text { reviderad 2013-10- } \\
17 \text { att gälla fr.o.m. } \\
\text { 2013-10-17. }\end{array}$ \\
\hline F & \multirow{2}{*}{2017} & $\begin{array}{l}\text { FR1111, Grundkurs, 30 } \\
\text { högskolepoäng, } \\
\text { att gälla fr.o.m. ht 2016 }\end{array}$ & $\begin{array}{l}\text { FR1200, } \\
\text { Fortsättningskurs, 30 } \\
\text { högskolepoäng, fastställd } \\
\text { 2011-04-06 reviderad } \\
\text { 2016-11-22 att gälla } \\
\text { fr.o.m. 2017-01-16. }\end{array}$ & $\begin{array}{l}\text { FR1303, Fördjup- } \\
\text { ningskurs del I, 15 } \\
\text { högskolepoäng, } \\
\text { fastställd 2011-05-03 } \\
\text { reviderad 2016-06- } \\
\text { 21 att gälla fr.o.m. } \\
\text { 2016-08-29. }\end{array}$ \\
\hline
\end{tabular}

Bilaga 2: Fastställande instans för kursplanerna frän de olika perioderna

\begin{tabular}{l|l|l}
\multicolumn{2}{|c}{ Fastställande instans } \\
A & Före 1977 & $\begin{array}{l}\text { Normalstudieplan fastställd Universitetskanslerämbetet i } \\
\text { Stockholm (i samråd med Skolöverstyrelsen). }\end{array}$ \\
\hline B & $1977-1993$ & Göteborgs universitet (linjenämnd) \\
\hline C & $1994-2006$ & Humanistiska fakulteten \\
\hline D & $2007-2011$ & Humanistiska fakulteten \\
\hline E & $2012-2016$ & Institutionen för språk och litteraturer \\
\hline F & 2017 & Institutionen för språk och litteraturer \\
\hline
\end{tabular}

